\title{
Social Networking Sites and Deviance among Youth in Islamabad, Pakistan
}

\author{
Ume Habiba $^{1}$, Neelam Farid ${ }^{2} \&$ Muhammad Saud $^{3}$ \\ ${ }^{1,2}$ Department of Sociology, International Islamic university Islamabad, Pakistan \\ ${ }^{3}$ Department of Sociology, Universitas Airlangga, Surabaya, Indonesia
}

\begin{tabular}{|c|c|}
\hline ARTICLE INFO & ABSTRACT \\
\hline $\begin{array}{l}\text { Keywords: } \\
\text { Pakistan } \\
\text { Social Networking Sites } \\
\text { Youth } \\
\text { Deviance } \\
\text { Online Harassment }\end{array}$ & $\begin{array}{l}\text { The digital media transform the social scenario of Pakistan. We are } \\
\text { living in the era of information explosion. Social networking sites such } \\
\text { as Facebook, Twitter, Skype, Instagram and WhatsApp provide } \\
\text { platform to express our thoughts and share it with other people. Social } \\
\text { networking apps are utilized for information, knowledge, fun, music, } \\
\text { images and videos. It creates both positive and negative influence on } \\
\text { youth. Social media facilitated deviance among youth such as } \\
\text { pornography, black mailing, and online harassment. The current study } \\
\text { aimed to explore the role of social networking sites in promoting } \\
\text { deviance among youngsters' life. The present cross sectional research } \\
\text { applied quantitative methodology to explore this phenomenon. The } \\
\text { population comprised both male and female between the age of } 21-24 \\
\text { and universe confined to Islamabad. The sample size was } 323 \\
\text { youngsters from International Islamic University Islamabad, Pakistan. } \\
\text { The researcher administered survey conducted by utilizing } \\
\text { questionnaire. Stratified random sampling used to locate the } \\
\text { respondents in faculty of social science. Univariate and bivariate } \\
\text { analysis of the field data done by SPSS. Majority of the respondent } \\
\text { (98.3\%) used social networking sites and } 56.6 \% \text { respondents said } \\
\text { online harassment is done by these sites which effect women } \\
\text { dignity. } 68.9 \% \text { youngsters said social networking apps promote } \\
\text { deviance among youth and } 72.3 \% \text { said social networking apps promote } \\
\text { abusive language. On this basis of the findings, it can be concluded } \\
\text { that social media usage should be monitored and parents should have } \\
\text { awareness about the deleterious effect of social networking. }\end{array}$ \\
\hline
\end{tabular}

\section{Introduction}

Social networking sites are web based services that create virtual communities in which people connect and interact with friends, family and acquaintances. It offers a platform to share opinions, photos, music and videos on particular subject or just online hangout (Khurana, 2015; Murray \& Waller, 2007). Social networking apps can be utilized to refer as community based web sites, online discussions forums, chat rooms and other social spaces online. The main features of these sites included instant messaging, video calling, chat, file sharing, discussion groups, voice chats, blogging etc (Null, 2009 \& Kocak, G et al, 2013). Most extensive social networking sites are Twitter, Facebook, Instagram, WhatsApp, Snap chat, Viber and YouTube (Social Bakers, 2012).

Social networking Sites promote the interconnectedness and interdependence among culturally diverse people who live in any part of the world. These sits allow youngsters for social interaction and to communicate their point of view on different matters. Social Sites made this

* Corresponding Author E-Mail Address: muhhammad.saud@gmail.com 
world a global village where anyone communicate their opinion on different issues and promote interactive dialogues that build understanding of unlike opinions on various disputes (Ozguven,N., \& Mucan,B.,2013). Social Networking Sites also used for online shopping (Kaplan, A.M \& Haenliein, M, 2010). Youngsters have wide access to different technologies that keep them connected with each other. Social networking apps have been rapidly adopted by children and especially teenagers and young people worldwide, enabling new opportunities for the presentation of the self, Learning, construction of a wide circle of relationships, and the management of privacy and intimacy. (Lenhart, A., Madden, M., \& Hitlin, P. 2005; Lenhart \& Madden, 2007; Willaims \& Guerra, 2007).

Social Networking Sites Promote violence, aggression, verbal abuse, bullying, negative behavior, drug use, explicit sexual content, blackmailing, intimidation and moral degradation. Mali (2011) designates that the graphic, sexually explicit subordination of women via pictures or words that also include pornography is verbal or pictorial material which represents or describes sexual behavior that is degrading or abusive to one or more of participants in such a way as to endorse the degradation. The person has chosen or consented to be harmed, abused, subjected to coercion does not alter the degrading character of such behavior. Social networking apps has provided medium for the facilitation of crimes like pornography. Most cases are identified youngsters and children between the ages of 10 to 24 years. The young person can be the victim, the perpetrator, or both. The deviant behavior of youth includes verbal abuse, bulling, hitting, negative thinking, watch nude images and videos (Centerwall et al, 2008 .

Conceptual / Operational Framework

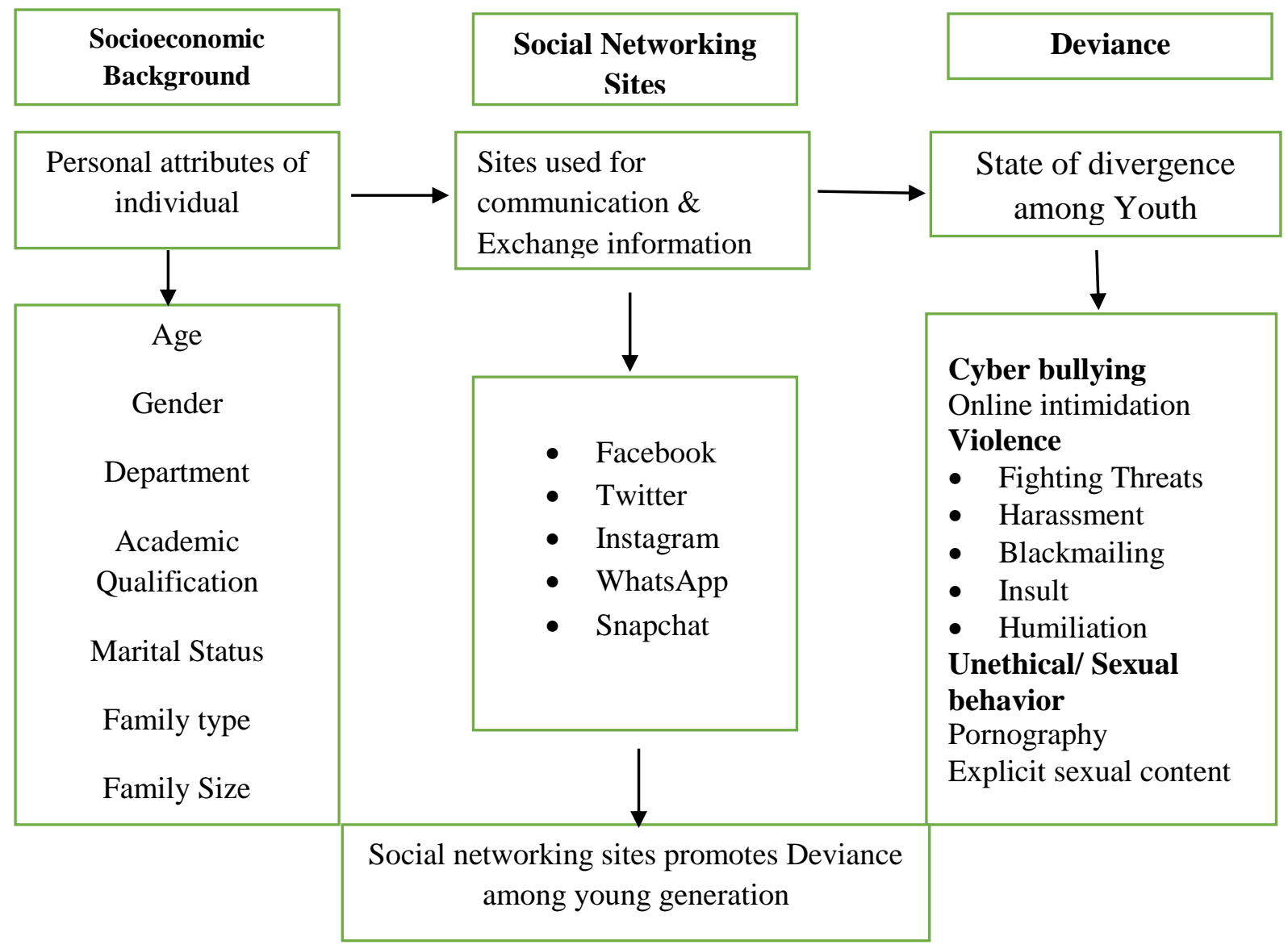

Pew research center (2018) enunciates that 3.1 billion social networking sites users around the globe in which 1.9 billion unique monthly users of Facebook, 1 billion unique monthly users of You Tube, 1 billion users of WhatsApp, 600 million unique users of Instagram, 317 million 
user of Twitter 260 million users of viber, 255 million users of snapchat and 106 million users of LinkedIn. More the 44 million user of social networking sites were recorded in 2017.

This research strived to unleash the role of social networking sites in promoting deviance among youth in Islamabad. It's a general perception that social networking sites are utilized for communication and entertainment but these sites employed for deviant acts like cyber bullying, black mailing, verbal and emotional abuse. More exclusively, this research focused on the way in which social sites (Facebook, Twitter, WhatsApp, Viber, Snapchat) influence the young generation and promote social deviance among youth. Mostly students are using these social networking apps so the researcher select university students for survey.

\section{Methodology:}

\section{Theoretical Foundation of the research}

The researcher applied Bandura"es Social Learning Theory $(1971,1997)$ and Bourdieu Social capital theory (1986). Youngsters use social networking sites for communication and create virtual social capital. Social network sites offer a platform for young people to create personal and social interconnected and interdependent virtual community where they share their personal data on the base of trust but some divergent youngsters exploit other young people. Linking this theory with my research young personnel learns deviant acts from one another via continuous reciprocal interaction from observation, imitation and modelling and attitude of other young individuals. Further linking people use social networking for information and knowledge. People watch films, unethical videos and images for fulfill their sexual needs and satisfaction. The young adults utilized users' personal information for blackmailing.

\section{Methods and Materials}

This study is quantitative in nature and researcher conduct survey by using self-administrated questionnaire. Proportionate stratified sampling was used to select the sample from four sections in international Islamic University Islamabad. The sample selected 323 male and female university students from diverse departments from the faculty of social science. The researcher did pretesting of questionnaire before going to field for data collection. The data was analyzed by utilizing SPSS version 22. Chi square has been used to determine association among variables.

\section{Results and Discussion}

The researcher has performed both univariate and bivariate quantitative analysis of collected from the field. Socio-economic background plays decisive role in the interpretation of data.

Univariate descriptive analysis of baseline socio-demographic characteristics of ever-married women age 15-49 who have heard of hepatitis $\mathrm{B}$ or $\mathrm{C}$, the percentages who believe that hepatitis can be avoided by different ways with reference to PDHS 2012-13. $(n=5661)$

Table No 1: Socio-economic Background

\begin{tabular}{|l|l|l|l|}
\hline Variables & \multicolumn{1}{|l|}{ valid \% } & Variables & valid \% \\
\hline Departments & \multicolumn{3}{|l|}{ Family Income } \\
\hline Education & $35(10.8 \%)$ & Below 10,000 & $2(6 \%)$ \\
\hline Media & $88(27.1 \%)$ & $20,000-30,000$ & $9(2.8 \%)$ \\
\hline Economics & $45(13.9 \%)$ & $30,000-40,000$ & $78(24 \%)$ \\
\hline Sociology & $110(34.1 \%)$ & 50,000 and above & $234(72 \%)$ \\
\hline Psychology & $45(13.95 \%)$ & Family Type & \\
\hline Marital Status & $38(12.5 \%)$ & Nuclear & $215(66.2 \%)$ \\
\hline Married & Joint & $72(22.2 \%)$ \\
\hline Unmarried & $287(88.3 \%)$ & Extended & $287(88.3 \%)$ \\
\hline
\end{tabular}




\begin{tabular}{|c|c|c|c|}
\hline Variables & valid \% & Variables & valid \% \\
\hline \multicolumn{2}{|c|}{ Age in 5 years } & \multicolumn{2}{|c|}{ Use of Social Networking Sites } \\
\hline $15-19$ & $27(8.3 \%)$ & Yes & $303(93.2 \%)$ \\
\hline $20-24$ & $242(74.5 \%)$ & No & $20(6.2 \%)$ \\
\hline Above 30 & $3(9 \%)$ & Yes & 19.8 \\
\hline \multicolumn{2}{|c|}{ Usage of Social Networking Sites in Hours } & \multicolumn{2}{|c|}{ Use of Device for social networking sites } \\
\hline $1-3$ & $107(32.9 \%)$ & $\begin{array}{l}\text { Through cell } \\
\text { phone }\end{array}$ & $253(77.8 \%)$ \\
\hline $4-6$ & $114(35.1 \%)$ & $\mathrm{Pc}$ & $11(3.4 \%)$ \\
\hline $7-9$ & $80(24.6 \%)$ & Laptop & $53(16.3 \%)$ \\
\hline Above 10 & $22(6.8 \%)$ & I. Pad & $6(1.8 \%)$ \\
\hline Total & $323(100 \%)$ & Total & $323(100 \%)$ \\
\hline
\end{tabular}

Table 1 shows the majority of the respondents were ages of $21-25$ and their percentage is $74.5 \%$ and having the age of above 30 were less in numbers. The young individuals $88.3 \%$ were unmarried and only $12.5 \%$ were unmarried. $34.1 \%$ respondents were belonging to the sociology department and $10.8 \%$ respondents was belonging to the education department. $66.2 \%$ university students were lived in nuclear family and $11.1 \%$ respondents were lived in extended family. The family income of $72 \%$ young students have above 50,000 and $6 \%$ have family monthly income was below 10,000. 93.2\% students used social networking apps in daily routine. 32.9\% respondents using social networking apps 1-3 hours in a day,35.1\% using 4-6 hours in a day, $24.6 \%$ respondents using 7-9 hours in a day and $6.8 \%$ respondents use above 10 hours social networking apps in a day. Highest frequency was 4 to 6 hours and the percentage was $35.1 \%$. Most of the respondents $77.8 \%$ use social networking apps in cell phone, and $3.4 \%$ use through PC, some of them 16.3\% use through Laptop and some of them $1.8 \%$ use through I. Pad. Most of the respondents use social networking apps in cell phone and their percentage is $77.8 \%$.

Table No 2: Perception of respondents about use of different social networking apps

\begin{tabular}{|l|l|l|l|l|l|l|}
\hline $\begin{array}{c}\text { Social } \\
\text { Networking } \\
\text { Sites }\end{array}$ & $\begin{array}{c}\text { To some } \\
\text { extent }\end{array}$ & $\begin{array}{c}\text { To great } \\
\text { extent }\end{array}$ & Not at all & Mean & $\begin{array}{c}\text { Standard } \\
\text { deviation }\end{array}$ & Total \\
\hline Facebook & $138(42.5 \%)$ & $176(54.2 \%)$ & $8(2.5 \%)$ & 1.60 & .555 & $323(100 \%)$ \\
\hline Twitter & $105(32.3 \%)$ & $43(3.2 \%)$ & $175(53.8 \%)$ & 2.22 & .907 & $323(100 \%)$ \\
\hline WhatsApp & $116(35.7 \%)$ & $173(53.2 \%)$ & $43(10.5 \%)$ & 1.75 & .633 & $323(100 \%)$ \\
\hline Instagram & $77(23.7 \%)$ & $157(48.3 \%)$ & $99(27.4 \%)$ & 2.04 & .717 & $323(100 \%)$ \\
\hline Snapchat & $23(16.3 \%)$ & $234(72 \%)$ & $36(11.1 \%)$ & 1.95 & .523 & $323(100 \%)$ \\
\hline
\end{tabular}

Table 2 indicated that respondents Facebook $42.5 \%$ said to some extent, majority $54.1 \%$ said to great extent and $2.5 \%$ said never. Mean is 1.60 and .555 is standard deviation. $32.3 \%$ said used twitter to some extent, 3.2.2\% said to great extent and $53.8 \%$ said not at all. Mean of twitter is 2.22 and .907 is standard deviation. $35.7 \%$ used skype to some extent, $53.2 \%$ said to great extent and $10.5 \%$ said not at all. Mean of using skype is 1.75 and .633 is standard deviation. $23.7 \%$ used Instagram to some extent, $48.3 \%$ said to great extent and $27.4 \%$ said not at all. Mean of Instagram is 2.04 and .717 is standard deviation. 16.3\% used WhatsApp to some extent, $72.0 \%$ said to great extent and $11.1 \%$ said not at all. Mean of WhatsApp is 1.95 and .523 is standard deviation. 
Table 3 Perception of respondents about the purpose of using social networking apps

\begin{tabular}{|l|c|c|c|c|c|c|c|c|}
\hline \multicolumn{1}{|c|}{ Statements } & $\begin{array}{l}\text { Strongly } \\
\text { Disagree }\end{array}$ & Disagree & Neutral & Agree & $\begin{array}{c}\text { Strongly } \\
\text { Agree }\end{array}$ & Mean & $\begin{array}{c}\text { Standard } \\
\text { Deviation }\end{array}$ & Total \\
\hline $\begin{array}{l}\text { Educational } \\
\text { Purpose }\end{array}$ & $6(1.8 \%)$ & $63(19.4 \%)$ & $\begin{array}{c}45 \\
(13.8 \%)\end{array}$ & $\begin{array}{c}184 \\
(56.8 \% \\
)\end{array}$ & $\begin{array}{c}25 \\
(7.7 \%)\end{array}$ & 3.49 & .953 & $323(100 \%)$ \\
\hline $\begin{array}{l}\text { Entertainme } \\
\text { nt }\end{array}$ & $6(1.8 \%)$ & $54(16.6 \%)$ & $\begin{array}{c}36 \\
(11.1 \%)\end{array}$ & $\begin{array}{c}182 \\
(56 \%)\end{array}$ & $\begin{array}{c}45 \\
(13.8 \%)\end{array}$ & 3.69 & .979 & $323(100 \%)$ \\
\hline Time Pass & $5(1.5 \%)$ & $58(17.8 \%)$ & $\begin{array}{c}33 \\
(10.2 \%)\end{array}$ & $\begin{array}{c}160.3 \% \\
(60)\end{array}$ & $\begin{array}{c}31 \\
(9.5 \%)\end{array}$ & 3.58 & .943 & $323(100 \%)$ \\
\hline $\begin{array}{l}\text { Connect } \\
\text { with friends }\end{array}$ & $5(1.5 \%)$ & $8(2.5 \%)$ & $13(4 \%)$ & $\begin{array}{c}156 \\
(48 \%)\end{array}$ & $\begin{array}{c}141 \\
(43 \%)\end{array}$ & 4.36 & .792 & $323(100 \%)$ \\
\hline $\begin{array}{l}\text { Online } \\
\text { Shopping }\end{array}$ & $7(2.2 \%)$ & $94(28.9 \%)$ & $\begin{array}{c}57 \\
(17.5 \%)\end{array}$ & $\begin{array}{c}151 \\
(46.5 \%\end{array}$ & $\begin{array}{c}13 \\
(3.4 \%)\end{array}$ & 3.21 & .983 & $323(100 \%)$ \\
\hline
\end{tabular}

Table 3 shows the frequency distribution purpose of social networking apps. Respondent use social networking apps for education purpose .1.8\% strongly disagreed, $19.4 \%$ disagreed, $13.8 \%$ neutral, $56.8 \%$ agreed and $7.7 \%$ strongly agreed. Mean of education purpose is 3.49 and standard deviation is .953. Respondent uses social networking apps for entertainment purpose. $1.8 \%$ strongly disagreed, $16.6 \%$ disagreed, $11.1 \%$ were neutral, $56.0 \%$ agreed and $13.8 \%$ strongly agreed with it. Mean of entertainment is 3.69 and .979 is standard deviation. Respondents use social networking apps for time pass. $1.3 \%$ strongly disagreed, $17.8 \%$ disagreed, $10.2 \%$ were neutral, $60.3 \%$ agreed and, $9.5 \%$ strongly agreed. Mean of time pass is 3.58 and standard deviation is .943 . Respondents use social networking apps for connect with friends' purpose. $1.5 \%$ was strongly disagreed, $2.5 \%$ were disagreed, $4.0 \%$ were neutral, $48.0 \%$ agreed and $43.0 \%$ strongly agreed. Mean of connect with friends is 4.36 and .792 is standard deviation. Respondents ${ }^{\text {ee }}$ uses social networking apps for online shopping purpose. $2.2 \%$ were strongly disagreed and, $28.9 \%$ were disagreed and, $17.5 \%$ were neutral, $46.5 \%$ were agreed and $3.4 \%$ were strongly agreed. Mean of online shopping is 3.21 and .983 is standard deviation. Social networking apps are virtual communities which allow people to connect and interact with each other on a particular subject or to just hang out together online (Murray \& Waller, 2007).

Beyond profiles, Friends, comments, and private messaging, social networking apps vary greatly in their features and user base. Some have photo-sharing or video-sharing capabilities; others have built-in blogging and instant messaging technology. Some web-based Social networking apps also support limited mobile interactions (e.g., Facebook, Instagram, WhatsApp, twitter). Many SNSs target people from specific geographical regions or linguistic groups, although this does not always determine the site's constituency (Kopytoff, 2004).

Table 4. Perception of respondents that online harassment effect women life

\begin{tabular}{|l|c|c|c|c|c|c|}
\hline \multicolumn{1}{|c|}{ Statements } & $\begin{array}{c}\text { To Some } \\
\text { Extent }\end{array}$ & $\begin{array}{c}\text { To Great } \\
\text { Extent }\end{array}$ & Not at all & Mean & $\begin{array}{c}\text { Standard } \\
\text { Deviation }\end{array}$ & Total \\
\hline Harm women dignity & $117(36 \%)$ & $184(56.6 \%)$ & $22(6.8 \%)$ & 1.71 & .587 & $323(100 \%)$ \\
\hline Psychological Problems & $193(59.4 \%)$ & $102(31.4 \%)$ & $28(8.6 \%)$ & 1.49 & .652 & $323(100 \%)$ \\
\hline Personal Life & $183(56 \%)$ & $104(32 \%)$ & $36(11.1 \%)$ & 1.54 & .687 & $323(100 \%)$ \\
\hline Loss of Confidence & $110(33.8 \%)$ & $87(26.8 \%)$ & $\begin{array}{c}126 \\
(38.8 \%)\end{array}$ & 2.05 & .855 & $323(100 \%)$ \\
\hline Suicidal Attempts & $138(42.5 \%)$ & $140(43.1 \%)$ & $45(13.8 \%)$ & 1.71 & .697 & $323(100 \%)$ \\
\hline
\end{tabular}


Table 4 indicates the frequency distribution of online harassment effect women dignity $36.0 \%$ said to some extent, $56.6 \%$ said to great extend and $6.8 \%$ said not at all. Mean of haram women dignity is 1.71 and .587 is standard deviation. Women have psychological problems.59.4\% said to some extent.31.4\% said to great extent and $8.6 \%$ said not at all. Mean of psychological problems 1.49 and .652 is standard deviation. Online harassment effect women personal life.56.0\% said to some extent, $32.0 \%$ to great extent and $11.1 \%$ said to not at all. Mean of personal life is 1.54 and .687 is standard deviation. Loss of confidence issues also effect women personality.33.8\% said to some extent, $26.8 \%$ said to not at all and $38.8 \%$ said to not at all. Mean of loss of confidence is 2.05 and .855 is standard deviation. Suicidal issues also increase in young generation due especially in girls.42.5\% said to some extent, $43.1 \%$ said to great extent and $13.8 \%$ said not at all. Mean of suicidal attempt is 1.71 and .697 is standard deviation.

Table 5: Perception of respondents that social networking apps promote deviance

\begin{tabular}{|l|c|c|c|c|c|l|}
\hline Statements & $\begin{array}{c}\text { To some } \\
\text { extent }\end{array}$ & $\begin{array}{c}\text { To great } \\
\text { extent }\end{array}$ & Not at all & Mean & $\begin{array}{c}\text { Standard } \\
\text { deviation }\end{array}$ & Total \\
\hline $\begin{array}{l}\text { Unethical images of } \\
\text { women }\end{array}$ & $153(47.1 \%)$ & $133(40.9 \%)$ & $37(11.4 \%)$ & 1.64 & .679 & $323(100 \%)$ \\
\hline Blackmailing & $125(38.5 \%)$ & $163(50.2 \%)$ & $34(10.5 \%)$ & 1.72 & .656 & $323(100 \%)$ \\
\hline Abusive Language & $62(19.1 \%)$ & $235(72.3 \%)$ & $26(8 \%)$ & 1.89 & .511 & $323(100 \%)$ \\
\hline Unethical videos & $111(34.2 \%)$ & $169(52.4 \%)$ & $42(12.9 \%)$ & 1.79 & .667 & $323(100 \%)$ \\
\hline Harassment & $138(42.5 \%)$ & $144(44.3 \%)$ & $41(12.6 \%)$ & 1.70 & .682 & $323(100 \%)$ \\
\hline
\end{tabular}

Table 5 shows the frequency shows the frequency distribution types of violence promote social networking apps. Unethical images of women promote violence. Majority $47.1 \%$ said to some extent $40.9 \%$ said to great extent and some of them $11.4 \%$ said unethical images of women never promote violence. Black mailing is another type of violence. Some respondents $38.5 \%$ said to some extent, majority $50.2 \%$ said to great extent and few members $10.5 \%$ said to black mailing not promote violence. Mean of black mailing is 1.72 and .656 is standard deviation. Abusive language is also promoting violence through social networking apps. Some of $19.1 \%$ said to some extent, majority $72.3 \%$ said to great extent and $8.0 \%$ said abusive language not promote violence. Mean of abusive language is 1.89 and .511 is standard deviation. Unethical videos promote violence. Some of respondents $34.2 \%$ said to some extent, majority $52.4 \%$ said to great extend and $12.9 \%$ was said unethical videos not promote deviance.

Table 6 Perception of respondents about type of black mailing

\begin{tabular}{|l|c|c|c|}
\hline Statements & \multicolumn{1}{|c|}{ Yes } & No & Total \\
\hline Web Hacking & $253(77.8 \%)$ & $77(21.5 \%)$ & $323(100 \%)$ \\
\hline Bad images & $263 \%(80.9 \%)$ & $70(17.8 \%)$ & $323(100 \%)$ \\
\hline Unethical Videos & $235(72.5 \%)$ & $88(27.1 \%)$ & $323(100 \%)$ \\
\hline Account Hacking & $253(77.8 \%)$ & $70(21.5 \%)$ & $323(100 \%)$ \\
\hline Personal information & $207(63.5 \%)$ & $116(35.1 \%)$ & $323(100 \%)$ \\
\hline
\end{tabular}

Table 6 indicated the frequency distribution types of black mailing. Web hacking is a type of black mailing. Majority $77.8 \%$ said yes web hacking is type of black mailing. Some of them $21.5 \%$ said not agree with it. Bad images use is another type of black mailing. Majority $80.9 \%$ $\mathrm{k}$ was said bad image is type of black mailing and some of them $17.8 \%$ not agree with it. Unethical videos are used for black mailing. Most of the respondents $72.5 \%$ were said yes unethical videos are the type of black mailing, and 27.1\% not agree with it. Account hacking is another type of black mailing. Most of the respondents $77.8 \%$ said yes account hacking is the type of black mailing, and $21.5 \%$ were not agree with it. Personal information is also type 
if black mailing. Majority $63.5 \%$ of respondents said yes personal information is the type of black mailing. And 35.1\%.was not agree with it.

Table 7 Type of deviant behavior rapidly growth among youth

\begin{tabular}{|l|l|l|l|}
\hline Statements & Yes & No & Total \\
\hline Frustration & $222(68.3 \%)$ & $101(31.8 \%)$ & $323(100 \%)$ \\
\hline Fear & $216(66.5 \%)$ & $107(32.9 \%)$ & $323(100 \%)$ \\
\hline Aggressiveness & $184(56.6 \%)$ & $139(42.8 \%)$ & $323(100 \%)$ \\
\hline Threating & $205(63.1 \%)$ & $129(39.7 \%)$ & $323(100 \%)$ \\
\hline Physical violence & $194(59.7 \%)$ & $129(39.7 \%)$ & $323(100 \%)$ \\
\hline
\end{tabular}

Table 7 demonstrated the frequency distribution types of violent behavior rapidly grows in youth. Frustration is a type violent behavior. Majority $68.3 \%$ of the respondent said yes, and some of $31.8 \%$ respondents not agree the frustration is type of violent behavior. Fear is another type of violent behavior rapidly grows in youth. Most of the respondents $66.5 \%$ were said yes fear is type of violent behavior. Some of the respondents $42.8 \%$ were not agree with it. Aggressiveness encourages violent behavior in youth for black. Majority of the respondents 56 $.6 \%$ were said yes aggressiveness is type of violent behavior. Some of them $42.8 \%$ were not agreeing with it. Threating is another type of violent behavior. Majority $63.1 \%$ were said yes threating is type of violent behavior. And only $39.7 \%$ was not agreeing with it. Physical violence is another type of violent behavior. Majority $59.7 \%$ of the respondents were said yes physical violence is type of violent behavior. Some of the respondents $39.7 \%$ was not agreed with it.

Table 8 Use of abusive language in social networking apps

\begin{tabular}{|l|c|c|c|}
\hline Statements & Yes & No & Total \\
\hline Disgusting & $227(79.1 \%)$ & $96(20 \%)$ & $323(100 \%)$ \\
\hline Idiot & $227(79.1 \%)$ & $96(20 \%)$ & $323(100 \%)$ \\
\hline Abuse & $235(72.3 \%)$ & $88(27.1 \%)$ & $323(100 \%)$ \\
\hline Fuck & $217(66.8 \%)$ & $105(32.3 \%)$ & $323(100 \%)$ \\
\hline Sexy & $245(75.4 \%)$ & $78(24 \%)$ & $323(100 \%)$ \\
\hline
\end{tabular}

Table 8 uttered the frequency distribution type of comments use in social networking apps. Disgusting is type of comment uses in social networking apps. Highest frequency was 227 and a percentage was $79.1 \%$. Lowest frequency was 96 and a percentage was $20.0 \%$. Idiot is comment use in social networking apps. Highest frequency was 227 and percentage was $79.1 \%$. Lowest frequency was 96 and a percentage was $20.0 \%$. Abuse is type of comment uses in social networking apps. Highest frequency was 235 and percentage was $72.3 \%$. Lowest frequency was 88 and percentage was $27.1 \%$. fuck is comment and mostly use in social networking apps. Highest frequency was 217 and percentage was 66.8\%. Lowest frequency was 105 and percentage was $32.3 \%$. Sexy is mostly use comment in social networking apps. Highest frequency 245 and percentage was $75.4 \%$. Lowest frequency was 78 and percentage was $24.0 \%$.

Table 9 People watch unethical videos and images for different reasons

\begin{tabular}{|l|c|c|c|c|c|c|}
\hline Statement & $\begin{array}{c}\text { To some } \\
\text { extent }\end{array}$ & $\begin{array}{c}\text { To great } \\
\text { extent }\end{array}$ & Not at all & Mean & $\begin{array}{c}\text { Standard } \\
\text { Deviation }\end{array}$ & Total \\
\hline Satisfaction & $118(36.3 \%)$ & $143(44 \%)$ & $61(18.8 \%)$ & 1.83 & .734 & $323(100 \%)$ \\
\hline When set bored & $173(53.2 \%)$ & $85(26.2 \%)$ & $80(19.7 \%)$ & 1.66 & .790 & $323(100 \%)$ \\
\hline Enjoyment & $133(40.9 \%)$ & $110(33.8 \%)$ & $80(24 \%)$ & 1.84 & .797 & $323(100 \%)$ \\
\hline Depression & $112(34.5 \%)$ & $48(14.8 \%)$ & $162(49.8 \%)$ & 2.16 & .911 & $323(100 \%)$ \\
\hline
\end{tabular}

Tables 9 show the frequency distribution of people watch unethical videos and images for different purpose. Respondents watch unethical videos and images for satisfaction. Some of 
the respondents $36.3 \%$ said to some extent, most of them $44.0 \%$ said to great extent and $18.8 \%$ was not agree with it. Mean of satisfaction is 1.83 and .734 is standard deviation. Another reason of people watching unethical videos and images is when set bored. Majority $53.2 \%$ of respondents said to some extent, $26.2 \%$ said to great extent and few respondents $19.7 \%$ not agree with it.

Mean of when set bored is 1.66 and .790 is standard deviation. Another reason behind watching unethical videos and images is for enjoyment. Majority $40.9 \%$ of respondents said to some extent, $33.8 \%$ said to great extent and few respondents $24.0 \%$ not agree with it. Another reason behind watching unethical videos and images is depression. Some of them $34.5 \%$ said to some extent, $14.8 \%$ said to great extent and majority $49.8 \%$ of respondents were not agreed with it. People use social media for many reasons. First, the need for connection and interaction with other people is evident. As supported by Maslowes Hierarchy of Needs, people desire to fulfill a sense of belonging through support from relationships with others. After obtaining physiological and safety needs, people strive to achieve Maslowes third need of belonging. New social media provide this opportunity where people can communicate with others and belong to different networks via virtual communities on the Internet. (Boyd and Ellision, 2007).

Table 10 Measures suggested by respondents for the lessened deviance via social networking site

\begin{tabular}{|l|c|c|c|c|c|c|c|c|}
\hline \multicolumn{1}{|c|}{ Statements } & $\begin{array}{c}\text { Strongly } \\
\text { Disagree }\end{array}$ & Disagree & Neutral & Agree & $\begin{array}{c}\text { Strongly } \\
\text { Agree }\end{array}$ & Mean & $\begin{array}{c}\text { Standard } \\
\text { deviation }\end{array}$ & Total \\
\hline $\begin{array}{l}\text { Develop strong } \\
\text { Privacy Setting }\end{array}$ & $12(3.7 \%)$ & $15(4.6 \%)$ & $\begin{array}{c}12 \\
(3.7 \%)\end{array}$ & $\begin{array}{c}129 \\
(39.7 \%)\end{array}$ & $\begin{array}{c}155 \\
(47.7 \%)\end{array}$ & 4.24 & .992 & $\begin{array}{c}323 \\
(100 \%)\end{array}$ \\
\hline $\begin{array}{l}\text { Unnecessary } \\
\text { adds should be } \\
\text { removed }\end{array}$ & $3(.9 \%)$ & $\begin{array}{c}42 \\
(12.9 \%)\end{array}$ & $\begin{array}{c}15 \\
(4.6 \%)\end{array}$ & $\begin{array}{c}155 \\
(47.7 \%)\end{array}$ & $\begin{array}{c}108 \\
(33.2 \%)\end{array}$ & 4.00 & .994 & $\begin{array}{c}323 \\
(100 \%)\end{array}$ \\
\hline $\begin{array}{l}\text { Bane vulgar } \\
\text { Websites }\end{array}$ & $3(.9 \%)$ & $2(.6 \%)$ & $\begin{array}{c}11 \\
(3.4 \%)\end{array}$ & $\begin{array}{c}142 \\
(43.7 \%)\end{array}$ & $\begin{array}{c}165 \\
(50.8 \%)\end{array}$ & 4.44 & .681 & $\begin{array}{c}323 \\
(100 \%)\end{array}$ \\
\hline $\begin{array}{l}\text { Promote } \\
\begin{array}{l}\text { Secure } \\
\text { Websites }\end{array}\end{array}$ & $5(1.5 \%)$ & $1(.3 \%)$ & $6(1.8 \%)$ & $\begin{array}{c}148 \\
(45.5 \%)\end{array}$ & $\begin{array}{c}163 \\
(50.2 \%)\end{array}$ & 4.43 & .699 & $\begin{array}{c}323 \\
(100 \%)\end{array}$ \\
\hline $\begin{array}{l}\text { Must block or } \\
\text { report those } \\
\text { people use } \\
\text { vulgar } \\
\text { language }\end{array}$ & $4(1.2 \%)$ & $2(.6 \%)$ & $8(2.5 \%)$ & $\begin{array}{c}162 \\
(49.8 \%)\end{array}$ & $\begin{array}{c}147 \\
(45.2 \%)\end{array}$ & 4.38 & .687 & $\begin{array}{c}323 \\
(100 \%)\end{array}$ \\
\hline
\end{tabular}

Table 10 demonstrates the frequency distribution of the respondent's suggestion about the social networking apps violence. Develop strong privacy setting 3.7\% was strongly disagreed with it, $4.6 \%$ was disagreed, $4.6 \%$ was neutral and $39.7 \%$ were agreed and $47.7 \%$ were agreed with it. Mean of privacy setting is 4.24 and .992 is standard deviation. Unnecessary adds should must be removed $.9 \%$ was strongly disagreed, $12.9 \%$ was disagreed, $4.6 \%$ was neutral and $47.7 \%$ were agreed and $33.2 \%$ were strongly agreed with it. Mean of unnecessary adds is 4.00 and .994 is standard deviation. Bane vulgar websites $.9 \%$ was strongly disagreed, .6\% was disagreed, $3.4 \%$ was neutral and $43.7 \%$ were agreed and $50.3 \%$ were strongly agreed. Mean of vulgar websites is 4.44 and .681 is standard deviation. Promote secure websites $1.5 \%$ was strongly disagreed, . $3 \%$ was disagreed, $1.8 \%$ was neutral and $45.5 \%$ were agreed and $50.2 \%$ were strongly agreed with it. Mean of secure websites is 4.43 and .699 is standard deviation. Must block or report those people use vulgar language $1.2 \%$ was strongly disagreed, $.6 \%$ was disagreed, $2.5 \%$ was neutral and $49.8 \%$ were agreed and $45.2 \%$ were strongly agreed with it. Mean of block or report those people use vulgar language is $4.38 \%$ and .687 is standard deviation. 


\section{Bi-Variate analysis}

Bi-variate analysis is one of the simplest forms of quantitative (statistical) analysis. It involves the analysis of two variables, for the purpose of determining the empirical relationship between them, for instance independent and dependent variable. In order to see if the variables are related to one another, it is common to measure how those two variables simultaneously change together. Bi-variate analysis can be helpful in testing of hypothesis of association and causality.

Hypothesis. Social networking apps promote deviance among youth.

\begin{tabular}{|c|c|c|c|c|c|c|}
\hline & Promote deviance among youth \\
\hline $\begin{array}{c}\text { Social } \\
\text { Networking } \\
\text { Apps }\end{array}$ & $\begin{array}{c}\text { Strongly } \\
\text { Disagree }\end{array}$ & Disagree & Neutral & Agree & $\begin{array}{c}\text { Strongly } \\
\text { Agree }\end{array}$ & Total \\
\hline Yes & $4(1.3 \%)$ & $67(21 \%)$ & $34(10.7 \%$ & $193(60.5 \%)$ & $21(6.6 \%)$ & $319(100 \%)$ \\
\hline No & $1(25 \%)$ & $0(0 \%)$ & $1(25 \%)$ & $2(50 \%)$ & $0(0 \%)$ & $4(100 \%)$ \\
\hline Total & $5(1.5 \%)$ & $67(20.7 \%)$ & $36(11.1 \%)$ & $195(60.4 \%)$ & $21(6.5 \%)$ & $323(100 \%)$ \\
\hline Chi-Square: 16.316 & DF: 4 & \multicolumn{7}{c|}{ Significance Level: .003 } \\
\hline
\end{tabular}

The cross table explains the bi-variate analysis of an independent variable (social networking apps and its deviance among youth on dependent variable by using chi-squares technique few $1.3 \%$ respondents strongly disagreed with social networking apps violence promote unethical behavior among youth, $21.5 \%$ respondents disagreed, $10.7 \%$ respondent was neutral and majority of the respondents $60.5 \%$ were agreed and $6.6 \%$ strongly agreed with it.

\section{Findings and Discussion}

Internet plays a vital role in youth behavior. The internet is accessible and popular among youth. Through internet people connect with friends, and family members. A research found that $74.5 \%$ people who are between the ages of 21-25 are the most users of social networking apps. It was found that many users using social networking apps more than one. A research found that people use social networking apps for communication, fun and information. This research found that $71.7 \%$ people use social networks for communication. A research found that $40.3 \%$ people said social networking apps represent women attractive. Such harassment has a profound effect on targeted women. It discourages them from writing and earning a living online. It interferes with their professional lives. A research found that $98.8 \%$ people said the online harassment effect women. Harassment harms women's dignity and intelligence of equal worth. Social networking harassment imposes unique harms to women's physical and emotional well-being and also effect on women personal life. In that research $56.6 \%$ respondents said harassment effect women dignity.

Social networking apps promote different type of violence. Research found that $72.3 \%$ respondents said social networking apps promote abusive language however, research also find that 52.4\% respondents said social networking apps promote unethical videos. According to the researcher, found that $68.3 \%$ respondent said frustration increased violent behavior among youth. People use different type of comments in social networking apps. In that research $79.1 \%$ respondent use mostly word "idiot" in comments.

\section{Conclusion}

The contemporary sites of social networking on the Internet becomes have advanced capabilities technological that can provide the best opportunities and services for users to enable them to achieve all forms of communication and contact social and family. And it also saves the mechanisms that help them achieving the integration and involvement in the communities electronic in different interests in ways allows them to global openness to the different cultures. The current research was based on the use of social networking apps promote 
deviance. The use of social networking apps effect youth behavior. Mostly people used different social networking apps and these apps promote black mailing, abusive language and unethical videos and online harassment. This phenomenon has broadened the opportunity to engage in Deviant and abusive behaviors and has dramatically increased the access of potential offenders to a more expansive pool of victims (Per Research Center, 2018).

Social networking apps has provided medium for the facilitation of crimes like pornography. Violence can involve young persons, typically children, teenagers, and young adults between the ages of 21 and 24. The young person can be the target, the offender, or both, youngsters includes aggressive behaviors such as verbal abuse, bulling, hitting, negative thinking, unethical images, and videos.

This study has some recommendations that social networking apps is a powerful tool and is certainly here to stay, it is important that people understand that nothing exists without negative side effects. Greater concerns about online safety and sharing of personal information and photos. More limited sharing of information/pictures via the internet. If young adults and their caregivers are aware of the potential deleterious effects of social networking use, they can create healthy social media habits to protector against these potential effects. Parents should motivate the children to use internet for education purpose. Teacher motivation encourages students to improve their knowledge by using internet.

\section{References}

Bourdieu, P. (1986). The Forms of Capital. In: Richardson, J., handbook of Theory and research for the Sociology of education. West, CT: Greenwood: 241-58.

Boyd, D.M., and Ellison, N.B. (2007). Social network sites: Definition, history, and scholarship, Journal of Computer-Mediated Communication, 13(1).

Centerwall, C. R., Kerwood, D. J., Goodisman, J., Toms, B. B., \& Dabrowiak, J. C. (2008). New extracellular resistance mechanism for cisplatin. Journal of inorganic biochemistry, 102(5), 1044-1049.

http://www.socialbakers.com/facebookstatisticsaccessed in July 18, 2012

Kaplan, A. M., \& Haenlein, M. (2010). Users of the World, Unite! The Challenges and Opportunities

Khurana, N (2015). The impact of Social Networking Sites on The Youth. J Mass Communicat journalism, 5,285.

Koçak, N. G., Kaya, S., \& Erol, E. (2013). Social Media from the Review, 2(3), 22-29

Koçak, N. G., Kaya, S., \& Erol, E. (2013). Social Media from the Review, 2(3), 22-29

Koptyoff, (2007). Social network sites: Definition, history, and scholarship. Journal of Computer-MediatedCommunication, 13(1), 210-230.

Lenhart, A., \& Madden, M. (2007). Social networking websites and teens: An Overview. Lenhart, A., Madden, M., \& Hitlin, P. (2005). Teens and technology.

Murray, K. E., \& Waller, R. (2007). Social networking goes abroad. International Educator, 16(3).

Murray, K. E., \& Waller, R. (2007). Social networking goes abroad. International Educator, $16(3), 56$.

Null,C (2009), "how to avoid Facebook and twitter disasters" pcworld.com, August 2010 of Social Media. Business Horizons, 53, 59-68.

Özgüven, N., \& Mucan, B. (2013) The relationship between personality traits and social media use, Social Behaviour and Personality, 41(3), 517-528

Pew Research Center (2018) The Demographics of Social Media Users-2018, February. http://www.pewinternet.org/2018/03/01/social-media-use-in-2018/

Socialbakers. (2012). Facebook statistics by Country. 